\title{
Degradation of phenol using US/periodate/nZVI system from aqueous solutions
}

\author{
Seid-Mohammadi A. ${ }^{1}$, Asgari G. ${ }^{2}$, Shokoohi R. ${ }^{2}$, Baziar M. ${ }^{3}$, Mirzaei N. ${ }^{4}$, Adabi S. ${ }^{2}$ and Partoei K. ${ }^{5}$ \\ ${ }^{1}$ Social Determinants of Health Research Center, Department of Environmental Health Engineering, School of Public Health, Hamadan \\ University of Medical Sciences, Hamedan, Iran \\ 2Department of Environmental Health Engineering, School of Public Health, Hamadan University of Medical Sciences, Hamadan, Iran \\ ${ }^{3}$ Department of Environmental Health Engineering, School of Public Health, Tehran University of Medical Sciences, Tehran, Iran \\ ${ }^{4}$ Social Determinants of Health (SDH) Research Center, Department of Environmental Health Engineering, Kashan University of Medical \\ Sciences, Kashan, Iran \\ ${ }^{5}$ Department of Environmental Health Engineering, School of Public Health and Safety, Shahid Beheshti University of Medical Sciences, \\ Tehran, Iran
}

Received: 16/12/2018, Accepted: 07/05/2019, Available online: 10/05/2019

*to whom all correspondence should be addressed: e-mail: vazanah5@gmail.com

https://doi.org/10.30955/gnj.002990

\begin{abstract}
In the present work, the degradation of phenol from aqueous solutions was investigated using periodate/zero valent iron nanoparticle (nZVI) in the presence of ultrasound at a batch reactor. The Experimental tests were carried out using pre-designated concentrations of $\mathrm{nZVI}$, periodate, and $\mathrm{pH}$ ranging from 1-7 mM, 0.5-5 mM, 3-11 respectively. During the all experimental tests the ultrasonic reactor was operated at a fix frequency (40 kHz), temperature $(33 \pm 1)$ and power $(350 \mathrm{~W})$. The results of $\mathrm{nZVI} /$ periodate/ultrasound system on degradation of phenol showed that the removal efficiency was indeed affected by the amount of free radicals produced to initiate the oxidative decomposition of phenol. also, by increasing the nZVI loading to $3 \mathrm{mM}$ and periodate concentration to $3 \mathrm{mM}$, the efficiency of phenol removal was increased. Besides, the acidic $\mathrm{pH}(\mathrm{pH}=3)$ was found to be more effective than neutral and alkaline $\mathrm{pH}$ in degradation of phenol.
\end{abstract}

Keywords: Periodate, nZVI, ultrasound, phenol, degradation.

\section{Introduction}

Wastewater caused by industrial activities might be contained by various chemical compounds in the quantities that can change the quality of water resources. Many of these compounds are organic-based, toxic, and characterized by high stability in the environment (Rahmani et al., 2016). The presence of recalcitrant organic compounds in the environment is undesirable and will create various unpleasant undesirable consequences for all creatures (Baziar et al., 2018a). Phenol $\left(\mathrm{C}_{6} \mathrm{H}_{5} \mathrm{OH}\right)$, a well-known toxic and hazardous organic compound, has been widely utilized in several industries like pulp and paper, paint, petrochemical, herbicide and pesticide production (Azevedo et al., 2006; Manshouri et al., 2012;
Ghasemi et al., 2015). The wastewater generated from these industries might be introduced to the surface and groundwater. As a result, it can produce severe adverse effects on aquatic life as well as human health with exacerbating the water contamination issues (Zhong et al., 2011). Phenol has been listed by USEPA as a priority pollutant due to high perniciousness on human and biota, high permanence in the aquatic environment, low biological decomposition property, high carcinogenic and mutagenic nature (Azevedo et al., 2006). Consequently, the elimination of this compound and its derivatives from industrial effluent/wastewater is an environmental concern.

A number of treatment methods to eliminate the phenol from contaminated water and/or from industrial wastewater (e.g., treatment by biological, physicochemical and advanced oxidation process approaches) have been extensively investigated. From above mentioned procedures, the application of biological treatment compared to the other two methods has recently fallen out of favor due to the toxicity of phenol to the bacteria (the organism that is responsible for decomposition) as well as its low efficacy and long time needed for adaptation of the bacteria water contaminated with phenol. Physico-chemical techniques are usually needed after treatment or disposal of produced sludge (Alavi et al., 2018; Baziar et al., 2018b). In the last few decades, applications of AOPs in the aqueous solution have been increasingly used because of their good performance to degrade a broad range of persistent organic pollutants (Seidmohammadi et al., 2016; Seid-Mohamadi et al., 2015; Seidmohammadi et al., 2018; Naghan et al., 2015). The performance of AOPs are underlying the production of strong reactive intermediates, e.g. sulfate $\left(\mathrm{SO}_{4}^{-\bullet}\right)$, hydroxyl $\left(\mathrm{OH}^{\circ}\right)$ and iodyl $\left(\mathrm{IO}_{3}{ }^{\circ}\right)$ via different activation methods. Therefore, these 
strong intermediates can entirely degrade the persistent organic pollutants to $\mathrm{CO}_{2}$ and $\mathrm{H}_{2} \mathrm{O}$ or convert them to a less toxic product (Lee et al., 2014).

More recently, the application of periodate $\left(\mathrm{IO}_{4}^{-}\right)$as an oxy-anion in water treatment has attracted increasing attention (Saien et al., 2018). The interest underlying the periodate usage in decomposition of persistent organic pollutants are associated with its(I) relatively high oxidation potential (EO = $1.6 \mathrm{~V})$, (II) high dissolution capacity in water, (III) stability at room temperature and (IV) generation of free radicals (e.g. $\mathrm{IO}_{3}{ }^{\circ}, \mathrm{IO}_{4}{ }^{\circ}$ ) through reactions of intermolecular electron transfer (Lee et al., 2014). Although the oxidation potential of periodate anion is acceptable however, its oxidation reactions are relatively slow at a room temperature and also serve selectively to oxide the organic compounds. The previous studies confirmed that periodate can be activated by ultraviolet (UV) irradiation as illustrated by equations of 1 to 3 and produce free radicals of $\mathrm{IO}_{3}{ }^{\bullet}$ and $\mathrm{OH} \bullet$ which can degrade organic matters (e.g., 4-chlorophenol and dye), (see Equations 1 to 3) (Chia et al., 2004; Lee et al., 2004).

$\mathrm{IO}_{4}^{-}+\mathrm{hv} \rightarrow \mathrm{IO}_{3}^{\circ}+\mathrm{O}^{\circ-}$

$\mathrm{O}^{\bullet-}+\mathrm{H}^{+} \rightarrow \mathrm{OH}^{\bullet}$

$\mathrm{IO}_{3}{ }^{-}+4-\mathrm{CP} \rightarrow \mathrm{IO}_{3}^{-}+$oxidized products

A great substitution to UV irradiation is ultrasonic (US) radiation. US radiation influence on molecules is related to nucleation, cavitations along with formation of microbubbles. The micro- bubbles produced provide areas of high pressure in the system which can generate $\mathrm{OH}^{*}$ radicals through dissociation of water. Therefore ultrasonic radiation is mainly used in numerous technologies for water purification (Dobaradaran et al., 2018; Zhou et al., 2015; Ammar, 2016). The generated $\mathrm{OH}^{\bullet}$ radicals can non- selectively degrade the organic compounds, therefore they reduce the selective nature of periodate in degradation of organic compounds. Also, the main advantage of this method is high ability to degrade hazardous material

to non-hazardous end products (Lee et al., 2014; Harrabi et al., 2018). The combination of ultrasonic waves with oxidants like $\mathrm{IO}_{4}^{-}$can accelerate the removal of organic components from aqueous solutions (Seid-Mohamadi et al., 2015).

Moreover, it has been proven that addition of Nano zero valent iron (nZVI) along with an oxidant (e.g., persufate, hydrogen peroxide, etc.) in aqueous solutions can enhance the elimination of organic compounds by increasing the generation of powerful free radicals such as $\mathrm{OH}^{*}$ and $\mathrm{SO}_{4}{ }^{*}$ (Harrabi et al., 2018; Zhou et al., 2008). The most important feature of $\mathrm{nZVI}$ is its high surface area which can accelerate the production of oxidants (Baziar et al., 2018b). However, it is reported that the formation of iron oxide layers (passive layers) on the surface of $n Z \mathrm{VI}$ may dramatically reduce the reactivity of $\mathrm{nZVI}$ and retard the generation free radicals (Song et al., 2019). Hence, in the present work we evaluate the role of US radiation as a destructive agent of iron passive layer, as well as nZVI loading and periodate dosage as factors that can improve the performance of US/nZVI/IO ${ }_{4}^{-}$system for degradation of phenol.

\section{Materials and methods}

\subsection{Chemicals}

The chemicals used in this study are as follows: phenol (99.8\%; Merck Co.), Sodium periodate (99\%; SigmaAldrich), potassium ferricyanide (99\%; Merck Co.), 4-aminoantipyrine (98\%; Merck Co.), Nanoparticle Zero Valent Iron powder (97\%; particle size 30-60 nm; Merck Co.), $\mathrm{KH}_{2} \mathrm{PO}_{4}$ (>99\%, Sigma-Aldrich ), $\mathrm{K}_{2} \mathrm{HPO}_{4} \quad(>98 \%$; Sigma-Aldrich ), $\mathrm{NH}_{4} \mathrm{OH}$ (Merck Co.), $\mathrm{H}_{2} \mathrm{SO}_{4}$ and $\mathrm{NaOH}$ (Merck Co.).

\subsection{Experimental procedure}

All experimental tests were performed in an ultrasonic stainless steel reactor (LUC-model 405) with dimensions of $15 \mathrm{~cm} \times 13 \mathrm{~cm} \times 25 \mathrm{~cm}$ and with a total volume of $5 \mathrm{~L}$. Figure 1 shows the schematic diagram of used ultrasonic reactor which was operated at a fixed frequency $(40 \mathrm{kHz})$, temperature $(33 \pm 1)$ and power $(350 \mathrm{~W})$ during the all experimental tests. The ultrasonic reactor used in this study consists of three parts: (i) turbulent regime tank, (ii) ultrasonic generator, (iii) transformer.

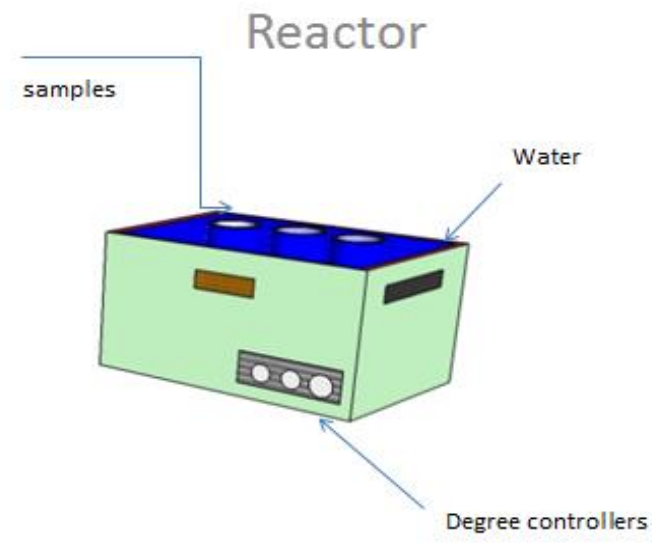

Figure 1. The schematic diagram of the ultrasonic reactor

To study the phenol degradation, the nZVI and sodium periodate with pre-designated concentrations (nZVI 0.5-5 $\mathrm{mM}$ and sodium periodate 1-7 $\mathrm{mM}$ ) were mixed with an appropriate concentration of phenol $(25-200 \mathrm{mg} / \mathrm{L})$ in a beaker with a final volume of $100 \mathrm{~mL}$. Then the solution $\mathrm{pH}$ (3-11) was adjusted with $\mathrm{H}_{2} \mathrm{SO}_{4}$ and $\mathrm{NaOH}(0.1 \mathrm{~mol} / \mathrm{L})$. The final solution was transferred to the ultrasonic stainless steel reactor (to get exposure with ultrasound waves) and stirred by a magnetic stirrer to obtain a homogenous solution within the process reaction times of 0-120 min. The initial and final concentration of phenol in samples was measured using UV-visible spectrophotometer at a wavelength of $500 \mathrm{~nm}$ (Deng et al., 2014). The removal efficiency of the developed system in various operation conditions was determined by Equation (4). 
$\operatorname{Removal}(\%)=\frac{C_{i}-C_{f}}{C_{i}} \times 100$

Here, $C_{i}$ and $C_{f}$ are related to the initial and final concentration of phenol in the developed system, consecutively. It is noted that, prior to phenol measurement in the samples, they were centrifuged for $5 \mathrm{~min}$ at a rotational speed of $1000 \mathrm{rpm}$ to remove the nZVI.

\section{Results and discussion}

\subsection{Effect of $\mathrm{pH}$ in $\mathrm{Us} / \mathrm{IO}_{4}^{-} / \mathrm{Fe}^{\bullet}$ system}

The effect of $\mathrm{pH}$ on phenol degradation in the $\mathrm{Us} / \mathrm{IO}_{4}{ }^{-} / \mathrm{Fe}{ }^{*}$ system was studied by changing its level between 3 and 11.It is quite obvious that in AOPs reactions the presence of several oxidants in the process increases the power of degradation. It is clear from Figure 2, the performance of Us $/ \mathrm{IO}_{4}{ }^{-} / \mathrm{Fe}^{\bullet}$ system was dependent upon the solution $\mathrm{pH}$ and it had significant influence in the range studied of 3-11. As the solution $\mathrm{pH}$ was increased the degradation percentage of phenol decreased. At $\mathrm{pH}$ value of 3 and contact time equal to $60 \mathrm{~min}$ the highest degradation percentage (88.4\%) was observed. Alkaline $\mathrm{pH} 11$ had the lowest removal percentage (49\%) in this study. The removal percentage of phenol was further investigated up to 120 minutes of contact time; it was found that after $60 \mathrm{~min}$ treatment, the removal percentage was changed slightly, so the optimum contact time was considered to be $60 \mathrm{~min}$ which also applied to the next steps of the experiment.

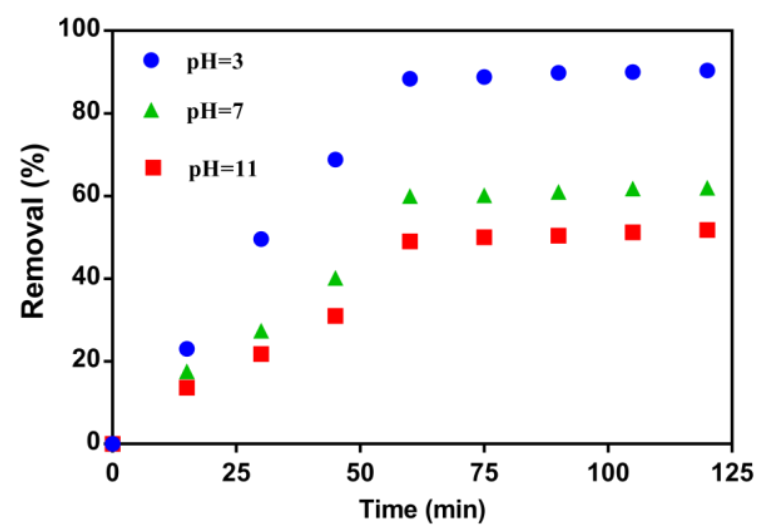

Figure 2. Effect of $\mathrm{pH}$ on the phenol degradation by $\mathrm{Us} / \mathrm{IO}_{4} / / \mathrm{Fe} \cdot$ system. $1 \mathrm{O}_{4}^{-} 5 \mathrm{mM}, \mathrm{NZVI} 2 \mathrm{mM}$, phenol $50 \mathrm{mg} / \mathrm{L}$

It is confirmed that the lower solution $\mathrm{pH}$ has more positive influence on phenol degradation than neutral and alkaline $\mathrm{pHs}$ in the $\mathrm{Us} / \mathrm{IO}_{4}{ }^{-} / \mathrm{Fe}^{-}$system. This might be due to the increasing concentration of hydrogen ions $\left(\mathrm{H}^{+}\right)$in the system at lower solution $\mathrm{pH}$, and therefore greater generation of $\mathrm{OH}^{\circ}$ and $\mathrm{IO}_{3}{ }^{\circ}$ radicals as the possible oxidants (see Equations 5 to 7) (Lee et al., 2014).

$$
\begin{aligned}
& \mathrm{IO}_{4}^{-}+\mathrm{H}^{\bullet} \rightarrow \mathrm{IO}_{3}{ }^{-}+\mathrm{OH}^{\bullet} \\
& \mathrm{IO}_{3}^{-}+\mathrm{H}^{\bullet} \rightarrow \mathrm{IO}_{2}{ }^{-}+\mathrm{OH}^{\bullet} \\
& \mathrm{IO}_{4}^{-}+\mathrm{H}^{\bullet} \rightarrow \mathrm{IO}_{3}{ }^{-}+\mathrm{OH}^{-}
\end{aligned}
$$

Basically, in the aqueous solutions $\mathrm{H}^{+}$ions are reduced to $\mathrm{H}^{\bullet}$ in the presence of $\mathrm{Fe}^{\bullet}$, also $\mathrm{pH}$ than 5 the $\mathrm{Fe}^{\bullet}$ convert to $\mathrm{Fe}^{\bullet}(\mathrm{OH}) 3$ and precipitates, thus compounds that have been attached to the nanoparticles are also deposited and removed from the solution (Deng et al., 2019). As a result, a large amount of $\mathrm{H}^{*}$ is generated by $\mathrm{Fe}^{\cdot}$ in acidic condition $(\mathrm{pH}=3)$ and $\mathrm{H}^{\circ}$ iseffective in generation of $\mathrm{IO}_{3}{ }^{\circ}$ and $\mathrm{OH}^{\bullet}$ free radicals. These free radicals are responsible for phenol degradation. However, the removal percentage was less in the basic and neutral $\mathrm{pH}$ than the acidic $\mathrm{pH}$. This performance can be due to the formation of iron based oxy-hydroxides in the system, like $\mathrm{FeOH}^{2+}$, Fe $\left(\mathrm{OH}_{2}\right)^{2+}$ and $\mathrm{Fe}_{2}(\mathrm{OH})_{2}{ }^{+4}$, which prevent the periodate activation as well as production of hydroxyl radicals (see Equations 8-10) (Schrick et al., 2002; Hussain et al., 2012).

$\mathrm{Fe}^{3+}+\mathrm{H}_{2} \mathrm{O} \rightarrow \mathrm{FeOH}^{2+}+\mathrm{H}^{+}$

$\mathrm{Fe}^{3+}+2 \mathrm{H}_{2} \mathrm{O} \rightarrow \mathrm{Fe}\left(\mathrm{OH}_{2}\right)^{2+}+2 \mathrm{H}^{+}$

$2 \mathrm{Fe}^{3+}+2 \mathrm{H}_{2} \mathrm{O} \rightarrow \mathrm{Fe}_{2}\left(\mathrm{OH}_{2}\right)^{4+}+2 \mathrm{H}^{+}$

Generally, two reaction pathways are assumed for free radical generation at the $\mathrm{pH}$ values ranging between acidic and neutral. The first is bringing the $\mathrm{H}^{*}$ in an acidic condition and second is bringing in the 1 electron transfer in a neutral condition by adjusting the initial solution $\mathrm{pH}$ in the process. However, the latter is not completely understood and there has not been an explanation for it recently (Lee et al., 2014).

In addition, in an acidic $\mathrm{pH}, \mathrm{Fe}^{\bullet}$ can enhance the degradation of phenol in the presence of dissolved $\mathrm{O}_{2}$ with a mechanism of 2- electron transfer and formation of hydrogen peroxide. The generated hydrogen peroxide can also reduce to $\mathrm{H}_{2} \mathrm{O}$ with a new reaction of 2- electron transfer. Next, the interaction between the hydrogen peroxide and ferrous iron $\left(\mathrm{Fe}^{2+}\right)$ can form $\mathrm{OH}^{\bullet}$ radicals. (see Equations 11 to 13) (Hussain et al., 2014).

$$
\begin{aligned}
& \mathrm{Fe}^{\bullet}+\mathrm{O}_{2}+2 \mathrm{H}^{+} \rightarrow \mathrm{Fe}^{2+}+\mathrm{H}_{2} \mathrm{O}_{2} \\
& \mathrm{Fe}+\mathrm{H}_{2} \mathrm{O}_{2}+2 \mathrm{H}^{+} \rightarrow \mathrm{Fe}^{2+}+2 \mathrm{H}_{2} \mathrm{O} \\
& \mathrm{Fe}^{2+}+\mathrm{H}_{2} \mathrm{O}_{2} \rightarrow \mathrm{Fe}^{3+}+\mathrm{OH}^{\bullet}+\mathrm{OH}^{-}
\end{aligned}
$$

\subsection{Effect of periodate concentration on the $\mathrm{Us} / \mathrm{IO}_{4}{ }^{-} / \mathrm{Fe}$ system}

The effect of periodate concentration on the performance of $\mathrm{Us} / \mathrm{IO}_{4}{ }^{-} / \mathrm{Fe}^{\bullet}$ system was investigated by adjusting the concentration from $1 \mathrm{mM}$ to $7 \mathrm{mM}$ and keeping $\mathrm{Fe}^{\cdot}$ concentration at $2 \mathrm{mM}$ with a reaction time ranging between 0-60 min. As illustrated in Figure 3, by increasing the periodate concentration from $1 \mathrm{mM}$ to $2 \mathrm{mM}$, the phenol removal efficiency increased from $86.2 \%$ to $93.6 \%$. However, further increasing the periodate concentration had negative influence on the system performance and the removal efficiency decreased. It is clear that the periodate concentration and its activation process play important roles in the enrichment of periodate reactive species (like $\mathrm{IO}_{4}{ }^{\circ}$ and $\mathrm{IO}_{3}{ }^{\circ}$ ) and the corresponding removal efficiency. When an adequate amount of periodate is fed 
to the system, in the presence of an activator, the removal efficiency increases. This trend can be explained by the production of free radicals in large enough amounts to degrade the organic compound. Although higher periodate concentrations (more than $2 \mathrm{mM}$ ) produce higher amounts of radicals, the generated radicals can react with each other or with $\mathrm{IO}_{4}^{-}$in a radical destructive reaction. Therefore, these reactions can reduce overall removal efficiency. Equation (14) presents an example of scavenging reaction which can occurr in the Us/10 $\mathrm{O}_{4}^{-} / \mathrm{Fe}^{\circ}$ system at an excess level of periodate concentration (Temiz et al., 2016).

$\mathrm{OH}^{\bullet}+\mathrm{IO}_{4}^{-} \rightarrow \mathrm{OH}^{-}+\mathrm{IO}_{4}{ }^{\circ}$

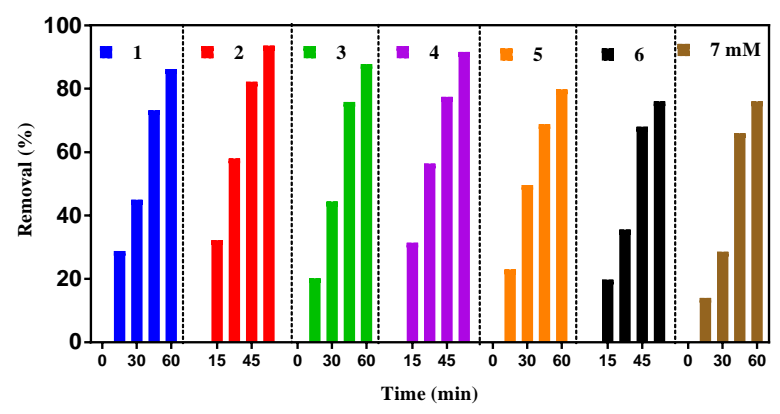

Figure 3. Effect of periodate concentration on the phenol degradation by Us $/ \mathrm{IO}_{4}-/ \mathrm{Fe} \cdot$ system. pH 3, NZVI 2 mM, phenol $50 \mathrm{mg} / \mathrm{L}$

\subsection{Effect of $\mathrm{NZVI}$ concentration on the $\mathrm{Us} / \mathrm{IO}_{4}{ }^{-} / \mathrm{Fe} e^{\bullet}$ system}

Figure 4 presents the phenol degradation under various $\mathrm{Fe}$ concentrations in the $\mathrm{Us} / \mathrm{IO}_{4}{ }^{-} / \mathrm{Fe}{ }^{\bullet}$ system. As seen, the phenol degradation was extensively impacted by $\mathrm{Fe}^{\bullet}$ loading and the phenol degradation percentage improved from $0 \%$ to $96.6 \%$ when $\mathrm{Fe}^{\bullet}$ concentration increased from 0 to $3 \mathrm{mM}$ in the system. This pattern can be explained by: (i) an increase in the total surface area with increasing the $\mathrm{Fe}^{\bullet}$ loading, which creates a contribution to the increase in the iron corrosion, (ii) an increase in the corrosion products (like $\mathrm{Fe}^{2+}, \mathrm{Fe}^{3+}$, etc.) by increasing the $\mathrm{Fe}^{\cdot}$ loading in an acidic medium that can produce free radicals to decompose the phenol (Baziar et al., 2018a). However, further increasing the $\mathrm{Fe} \cdot$ loading (more than 3 $\mathrm{mM}$ ) led to the reduction of system performance and, as the result, the removal percentage of phenol decreased.

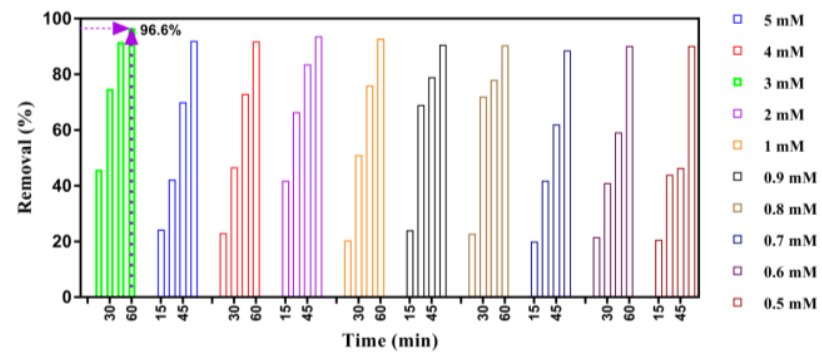

Figure 4. Effect of NZVI concentration on the phenol degradation by Us $/ \mathrm{IO}_{4} / / \mathrm{Fe}^{\bullet}$ system. $\mathrm{pH} 3$, periodate $2 \mathrm{mM}$, phenol $50 \mathrm{mg} / \mathrm{L}$
As mentioned above, $\mathrm{Fe}^{\bullet}$ can decompose an organic pollutant through transfer of two electrons to the dissolved oxygen to generate hydrogen peroxide (Equation 11). The hydrogen peroxide formed can be converted to $\mathrm{H}_{2} \mathrm{O}$ with another transfer of two electrons from $\mathrm{Fe}^{\bullet}$ (Equation 12). The products of reactions $\left(\mathrm{H}_{2} \mathrm{O}_{2}\right.$ and $\mathrm{Fe}^{2+}$ ) can be combined together to produce the Hydroxyl free radicals. However, with excessive loading (concentration) of $\mathrm{Fe}^{\bullet}$, a large amount of $\mathrm{Fe}^{2+}$ is produced. It can scavenge hydroxyl free radical via following reaction (Tang et al., 2008):

$\mathrm{Fe}^{2+}+\mathrm{OH}^{\bullet} \rightarrow \mathrm{Fe}^{3+}+\mathrm{OH}^{-}$

Therefore, the obtained results propose that, if the dosages of $\mathrm{Fe}^{\cdot}$ and periodate exceed the optimal value, the removal efficiency decreases subsequently. This work demonstrated that the addition of sufficient dosages of the $\mathrm{Fe}^{\cdot}$ and periodate were greatly important in decomposing phenol in water solutions.

\subsection{Effect of initial phenol concentration on $\mathrm{Us} / \mathrm{IO}_{4}{ }^{-} / \mathrm{Fe}^{-}$ system}

Figure 5 shows the performance of the developed system with phenol concentrations varying from 25 to $200 \mathrm{mg} / \mathrm{L}$ while other parameters were fixed at their optimum values. The highest removal percentage (99.6\%) was obtained when the phenol concentration was $25 \mathrm{mg} / \mathrm{L}$. As observed in Figure 5, by increasing the initial phenol concentration from 25 to $200 \mathrm{mg} / \mathrm{L}$, the removal efficiency decreased from $99.6 \%$ to $20.4 \%$ within 60 min. Generally, when a high level of phenol concentration was fed into the system, the molecules of phenol could be adsorbed on the surface of $\mathrm{Fe}^{\mathrm{o}}$ then these molecules, by decreasing the number of active sites on the surface of iron atom (Hansson et al., 2012), reduce the activation of periodate as well as the generation of $\mathrm{OH}$ radicals. Therefore, the removal efficiency decreases due to the inadequate generation of free radicals in the system.

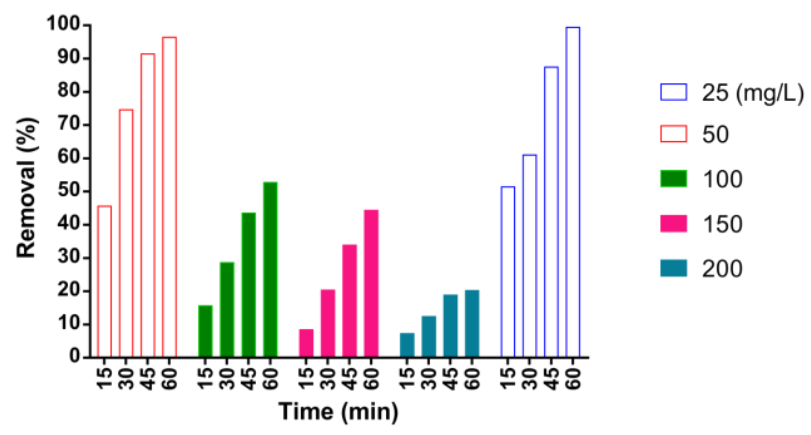

Figure 5. Effect of phenol concentration on the phenol degradation by $\mathrm{Us} / \mathrm{IO}_{4}-/ \mathrm{Fe}^{\circ}$ system. $\mathrm{pH} 3$, periodate $2 \mathrm{mM}, \mathrm{NZVI}$ $3 \mathrm{mM}$

In the next step of work, we compared the performance of $\mathrm{Us} / \mathrm{IO}_{4}^{-} / \mathrm{Fe} e^{-}$system with $\mathrm{US} / \mathrm{IO}_{4}^{-}$and $1 \mathrm{O}_{4}^{-} / \mathrm{Fe}{ }^{*}$, and also with $\mathrm{IO}_{4}^{-}$and US alone. In fact, the purpose of this stage of the study was to identify the function of each variable used in the system of $\mathrm{Us} / \mathrm{IO}_{4}^{-} / \mathrm{Fe}^{-}$for phenol 
decomposition. It is noted that the values of the parameters in the all systems were the same as the obtained optimal values of the parameters in the Us/ $\mathrm{IO}_{4}{ }^{-} / \mathrm{Fe}^{\bullet}$ system. Figure 6 shows the performance of $\mathrm{Us} / \mathrm{IO}_{4}{ }^{-} / \mathrm{Fe}^{\bullet}$ system with other developed treatment systems. As observed in Figure 6, merely $12 \%$ and $9.6 \%$ of phenol was decomposed within 60 min of treatment by US and $\mathrm{IO}_{4}$ alone, respectively, while $33.6 \%, 47.8 \%$ and $96.6 \%$ of phenol was decomposed in the systems of $\mathrm{IO}_{4}{ }^{-}$ $/ \mathrm{Fe}{ }^{\circ}, \mathrm{US} / \mathrm{IO}_{4}$ and $\mathrm{Us} / \mathrm{IO}_{4}{ }^{-} / \mathrm{Fe} e^{\bullet}$ respectively. The experiment results showed that US and $\mathrm{Fe}^{0}$ in the combined systems can play an outstanding role for enhancing the phenol decomposition. Generally, in the heterogeneous systems (similar to US/ $/ \mathrm{IO}_{4}^{-} / \mathrm{Fe}$ treatment) the main influence of US is abrasion and pitting on the surfaces of catalyst (Dobaradaran et al., 2018). US sweeps up the catalyst surfaces from attached intermediate products and it provides clean surfaces for next reactions. In addition, the aggregated $\mathrm{Fe}^{0}$ particles could be dispersed by US waves, thus the surface of active sites in the system increases. Furthermore, US radiation can lead to the generation of hydroxyl radicals (Equation 16) through dissociation of water molecules by producing micro-bubbles which provide the areas of high pressure (Dobaradaran et al., 2018).

$$
\mathrm{H}_{2} \mathrm{O}+\mathrm{US} \rightarrow \mathrm{OH}^{\bullet}+\mathrm{H}^{\bullet}
$$

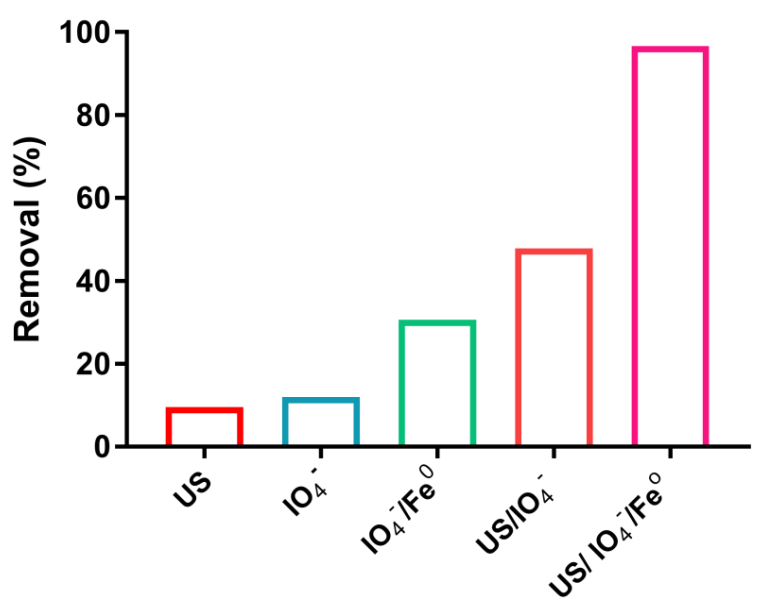

Figure 6. Effect of NZVI on periodate activation in the absence of ultrasonic waves on the phenol degradation. $\mathrm{pH} 3$, periodate $2 \mathrm{mM}$, NZVI $3 \mathrm{mM}$, phenol concentration $50 \mathrm{mg} / \mathrm{l}$, duration $60 \mathrm{~min}$

\subsection{Effect of $\mathrm{CaCl}_{2}$ on the degradation of phenol in Us} $/ \mathrm{IO}_{4} / \mathrm{Fe} e^{\bullet}$ system

In the natural water environments, the activation of $1 \mathrm{O}_{4}^{-}$ may be affected due to the presence of background ions. Hence, we investigated the influence of $\mathrm{CaCl}_{2}$, a compound or salt that can easily dissolve in aqueous solutions and generate ions of calcium and chloride. Three individual tests were performed to determine the effect of $\mathrm{CaCl}_{2}$ on the performance of $\mathrm{Us} / \mathrm{IO}_{4}{ }^{-} / \mathrm{Fe}{ }^{\bullet}$ system by adjusting the $\mathrm{CaCl}_{2}$ concentration in the values of 0.13 , 0.5 , and $1.03 \mathrm{~g} / \mathrm{L}$. As presented in Figure 7, the selected concentrations posed a little effect to the decomposition of phenol.

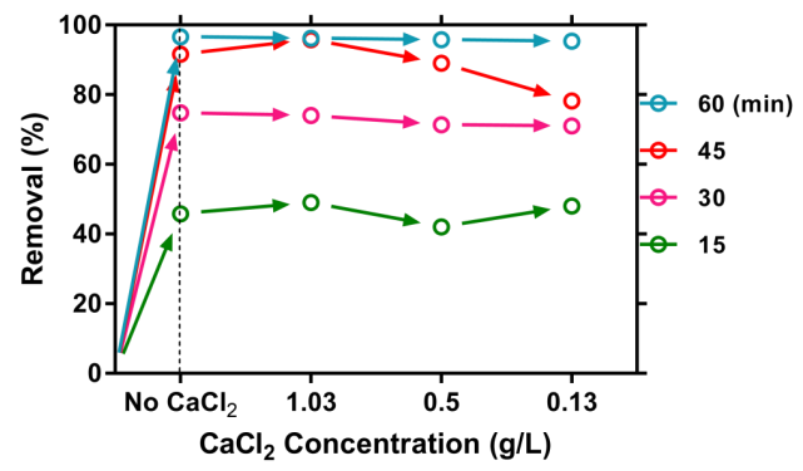

Figure 7. The impact of ion intensity on the decay of phenol in the Us $/ \mathrm{IO}_{4} / \mathrm{Fe}$ system. $\mathrm{pH}=3$, periodate $2 \mathrm{mM}, \mathrm{NZVI} 3 \mathrm{mM}$, phenol concentration $50 \mathrm{mg} / \mathrm{l}$, duration $60 \mathrm{~min}$

\section{6. $\mathrm{COD}$ removal in $\mathrm{Us} / \mathrm{IO}_{4}^{-} / \mathrm{Fe} e^{\bullet}$ system}

One of the most well-known methods for determination of persistent organic matter degradation in wastewater treatment is chemical oxygen demand (COD) (Baziar et al., 2018c). Determination of COD in our work is highly important, because of its potential to oxidize the organic pollutants like phenol using dichromate. In fact, the degree of oxidation of the process is determined by the extent of reduced COD. This test was conducted to find out the effectiveness of the process in degradation of phenol at the optimum values of parameters as determined in the previous steps. Figure 8 illustrates the performance of $\mathrm{Us} / \mathrm{IO}_{4} / \mathrm{Fe} e^{-}$on reduction of $\mathrm{COD}$ in a treatment test with three replications. As seen in this figure the performance of the developed system is about $85 \%$ in average. Therefore, it can be concluded that the process has high efficiency in eliminating COD. It is noted that for comparison we performed two separate tests using $\mathrm{Us} / \mathrm{IO}_{4}^{-}$and $\mathrm{IO}_{4}^{-} / \mathrm{Fe}^{-}$processes in the same conditions. The results showed that $\mathrm{Us} / \mathrm{IO}_{4}^{-}$and $1 \mathrm{IO}_{4}^{-} / \mathrm{Fe}$ can remove COD up to $38 \%$ and $29 \%$ on average, respectively.

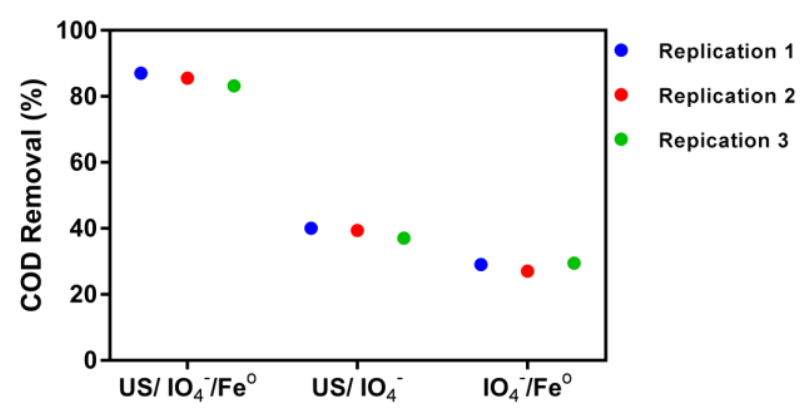

Figure 8. The impact of $\mathrm{Us} / \mathrm{IO}_{4}-/ \mathrm{Fe}^{\circ}$ systems (combined and isolated) for COD removal. $\mathrm{pH}=3$, periodate $2 \mathrm{mM}, \mathrm{NZVI} 3 \mathrm{mM}$, phenol concentration $50 \mathrm{mg} / \mathrm{l}$, duration $60 \mathrm{~min}$ 


\subsection{Proportion of $\mathrm{OH}$ radicals on degradation of phenol in the US/nZVI/periodate process}

In this study, tert-butyl alcohol (TBA) with a concentration of $1 \mathrm{M}$ was used to quench $\mathrm{OH}$ radicals in the $\mathrm{US} / \mathrm{nZVI} /$ periodate process with the aim of identifying the contribution of $\mathrm{OH}$ radical on degradation of phenol. In the previous studies, it has been demonstrated that TBA with no alpha hydrogen can completely destroy the hydroxyl radicals in aqueous solutions (Baziar et al., 2018b). It is marked from the laboratory radical scavenger test that the addition of TBA extensively decreased the decomposition of phenol. As already mentioned, the degradation of phenol in the optimized conditions of the process was $96.6 \%$ (without using radical scavenger). The addition of TBA, however, decreased the phenol decomposition to $43.2 \%$. Therefore, it can be concluded that the contribution of hydroxyl radical to the degradation of phenol in optimal conditions is $56.4 \%$ and the share of other radicals (like $\mathrm{IO}_{4}, \mathrm{IO}_{3}$ ) is $43.2 \%$.

3.8. Kinetic of phenol decomposition in the $\mathrm{Us} / \mathrm{IO}_{4}^{-} / \mathrm{Fe}^{-}$ system

In this experiment, the effects of different parameters such as periodate concentration, nZVI loading; $\mathrm{pH}$ and initial phenol concentration on the kinetic of phenol decomposition were studied using modified LangmuirHinshelwood model (Equation 17) (Dobaradaran et al., 2018). Table 1 shows the constant of first-order reaction rate ( $k$-value) and the determination coefficient $\left(R^{2}\right.$-value) of each parameter used in the system. As observed in this table, the $R^{2}$ - values of all experimental tests were above 0.8 . These results support the conclusion that phenol degradation in the process of US/Periodate/nZVI follows a first-order kinetic model. In addition, it can be concluded that the reaction rate $(k)$ is significantly dependent on the concentration of phenol. For instance, at phenol concentration of $25 \mathrm{mg} / \mathrm{L}$, the decomposition rate of phenol was $0.0827 \mathrm{~min}^{-1}$, while the reaction rate at phenol concentration of $200 \mathrm{mg} / \mathrm{L}$ was decreased to $0.0039 \mathrm{~min}^{-1}$.

$$
\ln \left(\frac{C}{C}\right)=-k t
$$

where $\mathrm{k}$ is the rate constant; $\mathrm{C}$ and $\mathrm{C}$. are initial and final concentrations of phenol in the system.

Table 1. The effect of studied parameters on kinetics of phenol decomposition

\begin{tabular}{|c|c|c|c|c|c|}
\hline Parameter & Value & Equation & $\mathrm{k}_{0}\left(\mathrm{~min}^{-1}\right)$ & $\mathbf{R}^{\mathbf{2}}$ & $t_{1 / 2}(\min )$ \\
\hline \multirow[t]{6}{*}{ Periodate (mM) } & $1 \mathrm{mM}$ & $y=0.0329 x-0.1407$ & 0.0329 & 0.959 & 21.06382979 \\
\hline & $2 \mathrm{mM}$ & $y=0.0456 x-0.2208$ & 0.0456 & 0.9593 & 15.19736842 \\
\hline & $3 \mathrm{mM}$ & $y=0.036 x-0.2131$ & 0.036 & 0.9484 & 19.25 \\
\hline & $4 \mathrm{mM}$ & $y=0.0404 x-0.1786$ & 0.0404 & 0.9602 & 17.15346535 \\
\hline & $5 \mathrm{mM}$ & $y=0.0273 x-0.0783$ & 0.0273 & 0.9907 & 25.38461538 \\
\hline & $6 \mathrm{mM}$ & $y=0.0252 x-0.1092$ & 0.0252 & 0.9527 & 27.5 \\
\hline \multirow[t]{3}{*}{$\mathrm{pH}$} & 3 & $y=0.0347 x-0.1893$ & 0.0347 & 0.9379 & 19.97118156 \\
\hline & 7 & $y=0.0144 x-0.0418$ & 0.0144 & 0.9501 & 48.125 \\
\hline & 11 & $y=0.0105 x-0.027$ & 0.0105 & 0.9491 & 66 \\
\hline \multirow[t]{5}{*}{ Phenol (mg/L) } & 25 & $y=0.0827 x-0.6247$ & 0.0827 & 0.8083 & 8.379685611 \\
\hline & 50 & $y=0.0575 x-0.1556$ & 0.0575 & 0.9895 & 12.05217391 \\
\hline & 100 & $y=0.0127 x-0.0139$ & 0.0127 & 0.9965 & 54.56692913 \\
\hline & 150 & $y=0.01 x-0.0359$ & 0.01 & 0.984 & 69.3 \\
\hline & 200 & $y=0.0039 x+0.0119$ & 0.0039 & 0.9707 & 177.6923077 \\
\hline \multirow[t]{10}{*}{$\mathrm{nZVI}(\mathrm{mM})$} & 0.5 & $y=0.0336 x-0.2563$ & 0.0336 & 0.8576 & 20.625 \\
\hline & 0.6 & $y=0.0353 x-0.2617$ & 0.0353 & 0.8375 & 19.63172805 \\
\hline & 0.7 & $y=0.0339 x-0.2368$ & 0.0339 & 0.8783 & 20.44247788 \\
\hline & 0.8 & $y=0.0396 x-0.1106$ & 0.0396 & 0.964 & 17.5 \\
\hline & 0.9 & $y=0.0401 x-0.1289$ & 0.0401 & 0.9767 & 17.28179551 \\
\hline & 1 & $y=0.0431 x-0.2923$ & 0.0431 & 0.9234 & 16.07888631 \\
\hline & 2 & $y=0.0451 x-0.1151$ & 0.0451 & 0.9846 & 15.36585366 \\
\hline & 3 & $y=0.0575 x-0.1556$ & 0.0575 & 0.9895 & 12.05217391 \\
\hline & 4 & $y=0.0403 x-0.2702$ & 0.0403 & 0.9116 & 17.19602978 \\
\hline & 5 & $y=0.0399 x-0.2847$ & 0.0399 & 0.8811 & 17.36842105 \\
\hline
\end{tabular}

\section{Conclusion}

The results of this study revealed that the US/Periodate/nZVI system is robust in degradation of phenol with an initial concentration of $50 \mathrm{mg} / \mathrm{L}$ by $5 \mathrm{mM}$ nano zero valent iron, $3 \mathrm{mM}$ periodate at an ultrasonic reactor with a fix frequency $(40 \mathrm{kHz})$, temperature $(33 \pm 1)$ and power $(350 \mathrm{~W})$ within $1 \mathrm{~h}$. It is also established in the present work that phenol degradation by US/Periodate/nZVI system follows the first- order kinetics.
In addition, the results of COD removal showed that US/Periodate/nZVI system is effective in elimination of COD from aqueous solutions. It can be concluded that the developed system is a promising and effective method for degradation of phenol from water solutions.

\section{Acknowledgements}

The author appreciates the support of Department of Environmental Health Engineering, School of Public Health, 
Hamadan University of Medical Sciences. We thank Do. Mohammad Fazel Khalili for proofreading.

\section{References}

Alavi N., Eslami A., Rafiee M., Adabi S., Partoei K. and Saeedi A. (2018), Cadmium removal via Phanerochate Chrysosporium in integrating by using silver nanoparticles (AgNP). Journal of International Pharmaceutical Research, 45, 178-183.

Ammar H.B. (2016), Sono-Fenton process for metronidazole degradation in aqueous solution: Effect of acoustic cavitation and peroxydisulfate anion. Ultrasonics Sonochemistry, 33, 164-169.

Apha A. (1995), WPCF, Standard methods for the examination of water and wastewater, Washington, DC: American Public Health Association.

Azevedo E.B., de Aquino Neto F.R. and Dezotti M. (2006), Lumped kinetics and acute toxicity of intermediates in the ozonation of phenol in saline media. Journal of Hazardous Materials, 128(2-3), 182-191.

Baziar M., Nabizadeh R., Mahvi A.H., Naddafi K., Mesdaghinia A., Alimohammadi M. and Aslani H. (2018a), Sensitivity analysis and modeling of 4-chlorophenol degradation in aqueous solutions by an nZVI-sodium persulfate system. Desalination and Water Treatment, 112, 292-302.

Baziar M., Nabizadeh R., Mahvi A.H., Alimohammadi M., Naddafi K., Mesdaghinia A. and Aslani H. (2018b), Effect of dissolved oxygen/nZVl/persulfate process on the elimination of 4chlorophenol from aqueous solution: Modeling and optimization study. Korean Journal of Chemical Engineering, 1-9.

Baziar M., Nabizadeh R., Mahvi A.H., Alimohammadi M., Naddafi K. and Mesdaghinia A. (2018c), Application of Adaptive Neural Fuzzy Inference System and Fuzzy C-Means Algorithm in Simulating the 4-Chlorophenol Elimination from Aqueous Solutions by Persulfate/Nano Zero Valent Iron Process. Eurasian Journal of Analytical Chemistry, 13(1).

Chia L.H., Tang X. and Weavers L.K. (2004), Kinetics and mechanism of photoactivated periodate reaction with 4chlorophenol in acidic solution. Environmental Science and Technology, 38(24), 6875-6880.

Deng J., Shao Y., Gao N., Deng Y., Tan C. and Zhou S. (2014), Zero-valent iron/persulfate (Fe 0/PS) oxidation acetaminophen in water. International Journal of Environmental Science and Technology, 11(4):881-890.

Dobaradaran S., Nodehi R.N., Yaghmaeian K., Jaafari J., Niari M.H., Bharti A.K., Agarwal S., Gupta V.K., Azari A. and Shariatifar N. (2018), Catalytic decomposition of 2chlorophenol using an ultrasonic-assisted $\mathrm{Fe}_{3} \mathrm{O}_{4}-$ $\mathrm{TiO}_{2} @ \mathrm{MWCNT}$ system: Influence factors, pathway and mechanism study. Journal of Colloid and Interface Science, 512, 172-189.

Ghasemi S.M., Asgharnia H.A., Karimyan K. and Adabi S. (2015), Adsorption of Basic Blue3 (BB3) dye from aqueous solution by tartaric acid modified sunflower stem: Kinetics and Equilibrium studies. International Research Journal of Applied and Basic Sciences, 9(5), 686-694.

Hansson H., Kaczala F., Marques M. and Hogland W. (2012), Photo-Fenton and Fenton oxidation of recalcitrant industrial wastewater using nanoscale zero-valent iron. International Journal of Photoenergy, 2012.
Harrabi M., Ammar H.B., Mbarki K., Naifar I., Yaiche C., Aloulou F. and Elleuch B. (2018), Ultrasonic power improvement of flumequine degradation effectiveness in aqueous solution via direct and indirect action of mechanical acoustic wave. Ultrasonics Sonochemistry, 48, 517.

Hussain I., Zhang Y., Huang S. and Du X. (2012), Degradation of pchloroaniline by persulfate activated with zero-valent iron. Chemical engineering Journal, 203, 269-276.

Hussain I., Zhang Y. and Huang S. (2014), Degradation of aniline with zero-valent iron as an activator of persulfate in aqueous solution. RSC Advances, 4(7), 3502-3511.

Lee C. and Yoon J. (2004), Application of photoactivated periodate to the decolorization of reactive dye: reaction parameters and mechanism. Journal of Photochemistry and Photobiology A: Chemistry, 165(1-3), 35-41.

Lee H., Yoo H.Y., Choi J., Nam I.H., Lee S., Lee S., Kim J.H., Lee C. and Lee J. (2014), Oxidizing capacity of periodate activated with iron-based bimetallic nanoparticles. Environmental Science and Technology, 48(14), 8086-8093.

Manshouri M., Daraei H. and Yazdanbakhsh A.R. (2012), A feasible study on the application of raw ostrich feather, feather treated with $\mathrm{H}_{2} \mathrm{O}_{2}$ and feather ash for removal of phenol from aqueous solution. Desalination and Water Treatment. 41(1-3):179-185.

Naghan D.J., Azari A., Mirzaei N., Velayati A., Tapouk F.A., Adabi S., Pirsaheb M. and Sharafi K. (2015), Parameters effecting on photocatalytic degradation of the phenol from aqueous solutions in the presence of $\mathrm{ZnO}$ nanocatalyst under irradiation of UV-C light. Bulgarian Chemical Communications, 47(Specia), 14-18.

Rahmani A.R., Foroughi M., Noorimotlagh Z. and Adabi S. (2016), Hexavalent chromium adsorption onto fire clay. Avicenna Journal of Environmental Health Engineering, 3(1), 1-6.

Seid-Mohamadi A., Asgari G., Shokoohi R. and Adabi S. (2015), Phenol disgrace via Periodate in integrating by using Supersonic Radiation. Journal of Medicine and Life, $\mathbf{8}$ (Spec Iss 3), 233.

Seidmohammadi A., Asgari G. and Torabi L. (2016), Removal of Metronidazole using ozone activated persulfate from aqua solutions in presence of ultrasound. Journal of Mazandaran University of Medical Sciences, 26(143), 160-173.

Seidmohammadi A., Amiri R., Faradmal J., Lili M. and Asgari G. (2018), UVA-LED assisted persulfate/nZVI and hydrogen peroxide/nZVI for degrading 4-chlorophenol in aqueous solutions. Korean Journal of Chemical Engineering, 35(3), 694-701.

Saien J. and Fallah Vahed Bazkiaei M. (2018), Homogenous $\mathrm{UV} /$ periodate process in treatment of $p$-nitrophenol aqueous solutions under mild operating conditions. Environmental Technology, 39(14), 1823-1832.

Schrick B., Blough J.L., Jones A.D. and Mallouk T.E. (2002), Hydrodechlorination of trichloroethylene to hydrocarbons using bimetallic nickel-iron nanoparticles. Chemistry of Materials, 14(12):5140-5147.

Song Y., Fang G., Zhu C., Zhu F., Wu S., Chen N., Wu T., Wang Y., Gao J. and Zhou D. (2019), Zero-valent iron activated persulfate remediation of polycyclic aromatic hydrocarboncontaminated soils: An in situ pilot-scale study. Chemical Engineering Journal, 355, 65-75.

Tang X. and Weavers L.K. (2008), Using photoactivated periodate to decompose TOC from hydrolysates of chemical warfare 
agents. Journal of Photochemistry and Photobiology A: Chemistry, 194(2-3):212-219.

Temiz K., Olmez-Hanci T. and Arslan-Alaton I. (2016), Zero-valent iron-activated persulfate oxidation of a commercial alkyl phenol polyethoxylate. Environmental Technology, 37(14):1757-1767.

Zhong W., Wang D., Wang Z. and Zhu L. (2011), Screening level risk assessment for phenols in surface water of three rivers in Tianjin, China. Graspa Working Papers, 1-4.

Zhou T., Li Y., Ji J., Wong F.S. and Lu X. (2008), Oxidation of 4chlorophenol in a heterogeneous zero valent iron $/ \mathrm{H}_{2} \mathrm{O}_{2}$ Fenton-like system: kinetic, pathway and effect factors. Separation and Purification Technology, 62(3), 551-558.

Zhou M., Yang H., Xian T., Li R.S., Zhang H.M. and Wang X.X. (2015), Sonocatalytic degradation of RhB over LuFeO3 particles under ultrasonic irradiation. Journal of Hazardous Materials, 289, 149-157. 